\title{
Impaired response to angiotensin II in Type 1 (insulin-dependent) diabetes mellitus. Role of prostaglandins and sodium-lithium countertransport activity
}

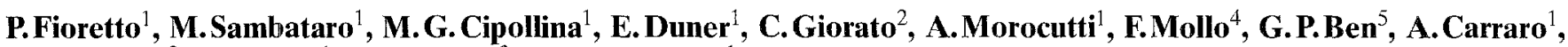 \\ D. Sacerdoti ${ }^{2}$, E.Brocco ${ }^{1}$, G. Opocher ${ }^{3}$ and R. Nosadini ${ }^{1}$
}

${ }^{1}$ Istituto di Medicina Interna, ${ }^{2}$ Istituto di Medicina Clinica and ${ }^{3}$ Istituto di Semeiotica Medica, Padova,

${ }^{4}$ Diabetic Clinical Center, Rovigo, and ${ }^{5}$ Diabetic Clinical Center, Agordo, Italy

\begin{abstract}
Summary. The pathogenesis of diabetic nephropathy remains elusive. A role for renal prostaglandins in antagonizing the hormonal effects of renin-angiotensin II has been postulated as a putative factor leading to hyperfiltration in patients with Type 1 (insulin-dependent) diabetes mellitus. Our aim was to elucidate the effects of angiotensin II on kidney haemodynamics and on blood pressure in eight normal subjects, in nine normotensive, in nine hypertensive with normal sodium-lithium countertransport activity in erythrocytes, in seven hypertensive without and in eight hypertensive Type 1 diabetic patients with microalbuminuria and with high sodium-lithium countertransport activity in erythrocytes. Angiotensin II infusion ( $4 \mathrm{ng} \cdot \mathrm{kg}^{-1} \cdot \mathrm{min}^{-1}$ for $60 \mathrm{~min}$ ) decreased the glomerular filtration rate to a greater extent in normal subjects $(-20 \%)$, than in normotensive patients $(-5 \% p<0.01)$, in hypertensive patients with normal sodium-lithium countertransport activity in erythrocytes $(-8 \% p<0.01)$ in hypertensive patients with high sodiumlithium countertransport $(-6 \% p<0.01)$ and in hypertensive microalbuminuric patients $(-5 \% p<0.01)$ with Type 1 diabetes. The urinary excretion rate of vasodilatory prostaglandins was two-three fold higher in all patients than in normal subjects. Acute indomethacin treatment restored a normal response to angiotensin II infusion in normotensive patients, but did not change the renal haemodynamic response in normal subjects. With regard to hypertensive patients with and without microalbuminuria indomethacin treatment restored a normal response to angiotensin II
\end{abstract}

in some but not all patients. An inverse relation was found between angiotensin II-induced decrease in the glomerular filtration rate and the sodium-lithium countertransport activity in erythrocytes during indomethacin treatment. Hypertensive and microalbuminuric patients with a sodiumlithium countertransport activity higher than $0.41 \mathrm{mmol} \cdot 1$ erythrocyte ${ }^{-1} \cdot \mathrm{h}^{-1}$ (the upper limit in normal subjects) also had a greater intimal plus medial thickness of the carotid artery using an ultrasonic imaging technique. Chronic indomethacin administration (30 days) significantly decreased the baseline overnight fasting glomerular filtration rate in normotensive and in hypertensive patients with normal but not in hypertensive and microalbuminuric patients with high sodium-lithium countertransport activity.

In conclusion these results demonstrate that: (1) excessive synthesis of vasodilatory prostaglandins antagonizes the regulation of renal haemodynamics by angiotensin II, at least partially accounting for hyperfiltration in Type 1 diabetes, (2) elevated sodium-lithium countertransport activity in erythrocytes identifies a subgroup of patients with Type 1 diabetes and hypertension, with and without microalbuminuria, in whom the normalization of urinary excretion rate of prostaglandins does not restore a normal response to angiotensin II.

Key words: Prostaglandins, angiotensin, sodium-lithium countertransport, hypertension, diabetic nephropathy.
One third of the patients with Type 1 (insulin-dependent) diabetes mellitus are at risk of developing renal disease [1, 2]. This subset of patients usually has an increased rate of glomerular filtration (GFR), microalbuminuria and elevation of arterial blood pressure prior to the development of overt nephropathy [3-5]. Moreover, it has recently been shown that high sodium-lithium countertransport activity in erythrocytes, a genetic marker of essential hypertension [6-7], characterizes patients with Type 1 diabetes and overt nephropathy [8], microalbuminuria [9] and glomerular hyperfiltration [10] although not all reports confirm this finding [11]. It has also been suggested that diabetic nephropathy is most common in patients with a family history of hypertension [9]. Patients with diabetic nephropathy often have elevated blood pressure, which has been presumed to be a consequence of renal damage. However, blood pressure in patients with Type 1 diabetes and microalbuminuria is often raised be- 
Table 1. Mean \pm SEM clinical and biochemical parameters ${ }^{a}$ of control subjects and Type 1 (insulin-dependent) diabetic patients (CD, $H_{1} D$, $\left.\mathrm{H}_{2} \mathrm{D}, \mathrm{H}_{3} \mathrm{D}\right){ }^{\mathrm{a}}$. Data refer to values obtained on the $2^{\text {nd }}$ day of admission during $200 \mathrm{mEq} /$ day sodium and $100 \mathrm{mEq} / \mathrm{day}$ potassium intake

\begin{tabular}{|c|c|c|c|c|c|}
\hline & $\begin{array}{l}\text { Normotensive } \\
\text { control subjects } \\
\text { (C) }\end{array}$ & $\begin{array}{l}\text { Normoten- } \\
\text { sive diabetic } \\
\text { patients } \\
\text { (CD) }\end{array}$ & $\begin{array}{l}\text { Hypertensive dia- } \\
\text { betic patients with nor- } \\
\text { mal } \mathrm{Na}^{+} / \mathrm{Li}^{+} \mathrm{C} \Gamma \\
\left(\mathrm{H}_{\mathrm{l}} \mathrm{D}\right)\end{array}$ & $\begin{array}{l}\text { Hypertensive dia- } \\
\text { - betic patients with } \\
\text { high } \mathrm{Na}^{+} / \mathrm{Li}^{+} \mathrm{CT} \\
\left(\mathrm{H}_{2} \mathrm{D}\right)\end{array}$ & $\begin{array}{l}\text { Hypertensive, microalbu- } \\
\text { minuric diabetic patients } \\
\text { with high } \mathrm{Na}^{+} / \mathrm{Li}^{+} \mathrm{CT} \\
\left(\mathrm{H}_{3} \mathrm{D}\right)\end{array}$ \\
\hline Gender (male:female) & $4: 4$ & $4: 5$ & $4: 5$ & $4: 3$ & $4: 4$ \\
\hline $\begin{array}{l}\text { Duration of antihypertensive } \\
\text { treatment (years) }\end{array}$ & - & - & $2.3 \pm 0.4$ & $2.1 \pm 0.2$ & $4.4 \pm 0.9^{c}$ \\
\hline Smokers $(\%)$ & 26 & 31 & 26 & 21 & 22 \\
\hline Blood pressure ( $\mathrm{mm} \mathrm{Hg}$ ) $\begin{array}{l}\text { Systolic } \\
\text { Diastolic }\end{array}$ & $\begin{array}{r}120 \pm 2 \\
80 \pm 2\end{array}$ & $\begin{array}{r}119 \pm 3 \\
78 \pm 2\end{array}$ & $\begin{array}{r}155 \pm 3^{b} \\
97 \pm 2^{b}\end{array}$ & $\begin{array}{r}158 \pm 3^{b} \\
95 \pm 3^{b}\end{array}$ & $\begin{array}{r}162 \pm 4^{b} \\
97 \pm 4^{b}\end{array}$ \\
\hline Body mass index $\left(\mathrm{kg} / \mathrm{m}^{2}\right)$ & $20 \pm 1$ & $21 \pm 1$ & $22 \pm 1$ & $22 \pm 2$ & $23 \pm 2$ \\
\hline $\begin{array}{l}\text { Plasma sodium concentration } \\
(\mathrm{mmol} / \mathrm{l})\end{array}$ & $140 \pm 2$ & $139 \pm 3$ & $140 \pm 2$ & $139 \pm 2$ & $140 \pm 3$ \\
\hline Potassium excretion (mmol/24 h) & $107 \pm 17$ & $99 \pm 22$ & $110 \pm 24$ & $104 \pm 19$ & $99 \pm 10$ \\
\hline Albumin excretion rate $(\mu \mathrm{g} / \mathrm{min})$ & $6 \pm 2$ & $8 \pm 3$ & $7 \pm 3$ & $10 \pm 3$ & $46 \pm 6^{b, c}$ \\
\hline Plasma glucose $(\mathrm{mmol} / \mathrm{l})$ & $4.7 \pm 0.2$ & $6.4 \pm 0.2^{b}$ & $6.4 \pm 0.3^{\mathrm{b}}$ & $7.2 \pm 0.3^{b}$ & $7.1 \pm 0.3$ \\
\hline $\begin{array}{l}\text { Plasma renin activity (ng angio- } \\
\text { tensin } \mathrm{I} / \mathrm{mL} / \mathrm{h} \text { ) }\end{array}$ & $1.9 \pm 0.2$ & $1.1 \pm 0.2^{a}$ & $1.3 \pm 0.3$ & $1.2 \pm 0.2$ & $1.4 \pm 0.3$ \\
\hline Serum creatinine $(\mathrm{mmol} / \mathrm{l})$ & $116 \pm 17$ & $107 \pm 17$ & $120 \pm 12$ & $119 \pm 17$ & $126 \pm 16$ \\
\hline
\end{tabular}

${ }^{\mathrm{a}} p<0.05,{ }^{\mathrm{b}} p<0.01, \mathrm{CD}, \mathrm{H}_{1} \mathrm{D}, \mathrm{H}_{2} \mathrm{D}$ and $\mathrm{H}_{3} \mathrm{D}$ patients vs $\mathrm{C}$ subjects; ${ }^{c} p<0.05 \mathrm{H}_{3} \mathrm{D}$ vs $\mathrm{H}_{2} \mathrm{D}, \mathrm{H}_{1} \mathrm{D}$ and $\mathrm{CD}$

$\mathrm{Na}^{+} / \mathrm{Li}^{+} \mathrm{CT}=$ sodium-lithium countertransport

fore any evidence of an impairment in renal function $[3,4$, 9].

These findings suggest that the mechanisms behind hypertension in Type 1 diabetes are still poorly understood.

It is well established that a relative or absolute overactivity of the renin-angiotensin system can cause or sustain hypertension and renal abnormalities. With regard to the hormonal regulation of kidney haemodynamics, the interaction of prostaglandins (PG) and renin-angiotensin II (Ang II) is known to modulate renal haemodynamics and sodium handling. In normal man $\mathrm{PGI}_{2}$ can stimulate the release of renin in the juxtaglomerular apparatus, and in turn Ang II in the renal interstitium, which is responsible for adjusting the vascular tone of the efferent glomerular artery and tubular sodium reabsorption $[12,13]$. Ang II in turn stimulates the release of $\mathrm{PGE}_{2}$ from renal interstitial cells [13], which inhibits sodium reabsorption in the renal medulla. An increased renal synthesis of $\mathrm{PGE}_{2}$ and $\mathrm{PGI}_{2}$ is frequently found in patients with Type 1 diabetes [14-17], together with low blood levels of renin and angiotensin II [14].

On the other hand an abnormal interaction of PGs and the renin-angiotensin system appears to characterize all patients with Type 1 diabetes [15-16], whereas only a subset of patients develops hypertension and nephropathy $[1$, $2,9]$. To gain further insights into the role of PGs and renin-angiotensin II in determining abnormalities in kidney function as well as hypertension in Type 1 diabetes, we studied the response to angiotensin II in diabetic patients with and without hypertension and microalbumin- uria before and after indomethacin treatment. The rationale of the selection criterion of diabetic patients was that hypertension, microalbuminuria and abnormalities in kidney haemodynamics have been shown to be associated in patients, who are at risk for developing diabetic nephropathy [3-5]. However, since it is not yet clearly established whether microalbuminuria alone or microalbuminuria together with hypertension and hyperfiltration can predict overt nephropathy, we studied Type 1 diabetic patients in whom these pathological conditions had occurred either together or separately.

\section{Patients and methods}

Twenty-four patients with Type 1 diabetes and hypertension, attending the Department of Internal Medicine, University of Padova, were recruited for the study in the North East region of Italy. A matched group of eight normotensive healthy subjects and nine normotensive Type 1 diabetic patients served as control subjects (Table 1).

Informed consent was obtained from all study participants and the study protocol was approved by the Ethical Committee of the University of Padova.

All subjects were Caucasian with normal serum creatinine concentrations. The presence of diabetes or impaired glucose tolerance was excluded by an abbreviated $75 \mathrm{~g}$ glucose tolerance test (baseline and $2 \mathrm{~h}$ blood glucose concentration) in non-diabetic subjects using the American Diabetes Association criteria. The same criteria were used to diagnose Type 1 diabetes in diabetic patients [18].

Blood pressure (diastolic phase $V$ ) was measured in the sitting position after $10 \mathrm{~min}$ rest to the nearest $2 \mathrm{~mm} \mathrm{Hg}$ using a Hawksley random zero sphygmomanometer $(12 \times 35 \mathrm{~cm}$ cuff $)$ and hypertension was defined as a blood pressure of $\geq 145 \mathrm{~mm} \mathrm{Hg}$ systolic and/or $\geq 90 \mathrm{~mm} \mathrm{Hg}$ diastolic in the absence of anti-hypertensive treatment. 
Causes of secondary hypertension were excluded by a complete medical examination which also included a 12-lead ECG. All subjects had normal liver and endocrine function, except for diabetes, and were following an isocaloric diet containing $50 \%$ carbohydrate, $25 \%$ fat and $25 \%$ protein. Patients were admitted to the metabolic ward of the Internal Medicine Department of the University of Padova for one week prior to the study and all anti-hypertensive medication was discontinued for at least 20 days prior to admission. No patient was taking amiloride or oral contraceptives. Patients were given a $200 \mathrm{mEq} \mathrm{Na}, 100 \mathrm{mEq} \mathrm{K}$ intake with a fluid intake of $1,500 \mathrm{ml} /$ day in the week preceding the renal haemodynamic evaluation both during placebo and indomethacin treatment. Timed overnight urine collections for urinary albumin measurement were performed at least four times over a period of 6 months preceding the study. The mean of all values for each patient was used for calculation.

\section{Procedures}

The day before the angiotensin II infusion the diabetic patients omitted the injection of intermediate-acting insulin and received short-acting insulin only at breakfast and lunch. At about 18.00 hours a constant intravenous infusion of insulin at a rate of $15 \mathrm{mU} \cdot \mathrm{kg}^{-1} \cdot \mathrm{h}^{-1}$ using a Harvard pump (Harvard Apparatus, Mills, Mass., USA) was started in order to achieve and maintain euglycaemia. Solid food, alcohol, coffee, tea and smoking but not tap water were prohibited after 22.00 hours. On the morning of the angiotensin II infusion test the overnight constant insulin infusion was stopped in the diabetic patients and both normal subjects and diabetic patients were connected to an artificial pancreas (Biostator, Miles Ames, Cavenago, Italy) in run mode 9:1 to perform a completely automatized blood glucose clamp at $4.7 \mathrm{mmol} / \mathrm{l}$. Thus, all experiments were performed under comparable conditions of fluid infusion $(0.5 \mathrm{ml} / \mathrm{min} 154 \mathrm{mmol} / \mathrm{l} \mathrm{NaCl}$ infusion) and Biostator driven euglycaemia. Diabetic patients received $14 \pm 6$ IU of regular insulin and normal subjects $2 \pm 1$ IU over the $330 \mathrm{~min}$ of the study. Experiments were performed under conditions of steady-state water diuresis and tracer blood concentrations as previously described [19-22]. Priming doses of $50 \mu \mathrm{Ci}$ of ${ }^{51} \mathrm{Cr}$-EDTA (Amersham, Amersham, UK) and $30 \mu \mathrm{Ci}$ of ${ }^{125} \mathrm{I}$-hippurate (Amersham) followed by a constant infusion of $0.7 \mu \mathrm{Ci} / \mathrm{min}$ and $0.2 \mu \mathrm{Ci} / \mathrm{min}$ of the two tracers respectively, were given via an antecubital vein of the opposite arm for determination of GFR and renal plasma flow (RPF) [19-22]. Measurements were started after 120 min of equilibration and with a urine osmolarity consistently below $75 \mathrm{mosmol} / \mathrm{kg}$. Patients remained supine throughout the experiment standing only to void urine. Three 30-min urine collections were made at the start of the experiment. At the midpoint of each urine collection period, blood samples were drawn, pulse rate taken, and blood pressure (diastolic phase $\mathrm{V}$ ) was measured to the nearest $2 \mathrm{~mm} \mathrm{Hg}$ using a standard mercury sphygmomanometer by a single observer (P.F.). Urine volume was measured and aliquots taken in plain tubes. A $3.5 \mathrm{ml}$ aliquot was also taken in a tube containing $20 \mu l$ gelatine $(10 \mathrm{~g} / \mathrm{dl})$ for protein measurements. Specimens for hormone measurements were collected in chilled tubes containing EDTA $(12 \mathrm{mg})$ and aprotinin (500 kallicrein-inhibitor U/ml blood) (Antagosan, Behring, Rome, Italy). All urine and blood samples were frozen immediately and stored at $-20^{\circ} \mathrm{C}$ until the assay.

\section{Angiotensin II infusion}

After the assessment of basal GFR and RPF, all subjects received an infusion of angiotensin II amide (Hypertensina, $4 \mathrm{ng} \cdot \mathrm{min}^{-1} \cdot \mathrm{kg}^{-1}$ diluted in $60 \mathrm{ml}$ (154 mmol/1 NaCl, Ciba Geigy, Basle, Switzerland) for $60 \mathrm{~min}$ using a Harvard infusion pump (Harvard Apparatus). The constant infusion of ${ }^{51} \mathrm{Cr}$-EDTA and ${ }^{125}$ I-hippurate continued throughout the angiotensin II infusion period to assess the changes in GFR and RPF. Blood pressure was monitored every $10 \mathrm{~min}$ with the cuff positioned over the brachial artery of the arm containing the sampling catheter (Study 1). All subjects received a $0.9 \%$ (weight/volume) $154 \mathrm{mmol} / \mathrm{l} \mathrm{NaCl}$ infusion containing $0.5 \%$ human

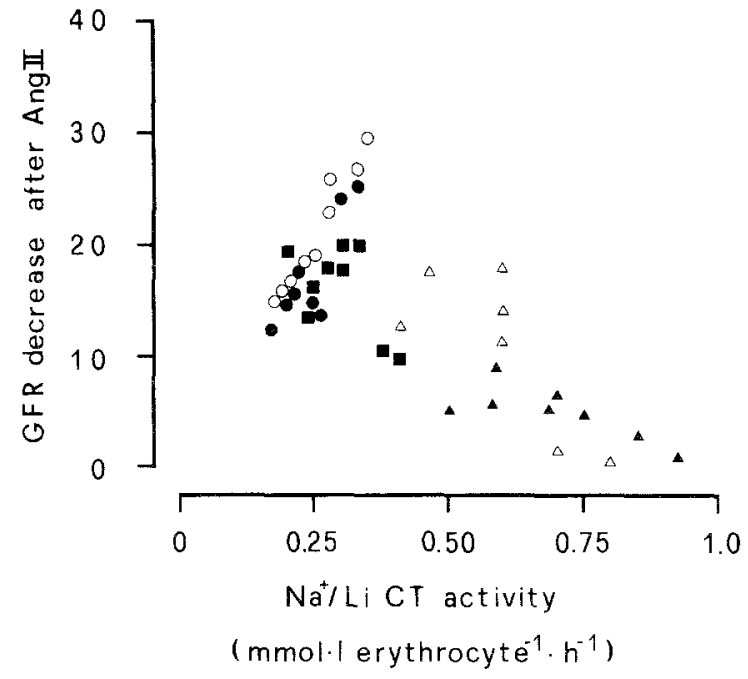

Fig. 1. Sodium-lithium countertransport $\left(\mathrm{Na}^{+} / \mathrm{Li}^{+} \mathrm{CT}\right)$ in erythrocytes and angiotensin II (Ang II)-induced decrease in glomerular filtration rate (GFR) during indomethacin treatment in eight normotensive control subjects ( $)$ and in 33 hypertensive patients with Type 1 (insulin-dependent) diabetes, nine normotensive $(O)$ and seven hypertensive with high $(\triangle)$, nine hypertensive with normal (a) and eight hypertensive with high $\mathrm{Na}^{+} / \mathrm{Li}^{+} \mathrm{CT}$ activity and microalbuminuria ( ) Type 1 diabetic patients. $\mathrm{R}_{S}=0.76, p<0.01$, Spearman Correlation Coefficient

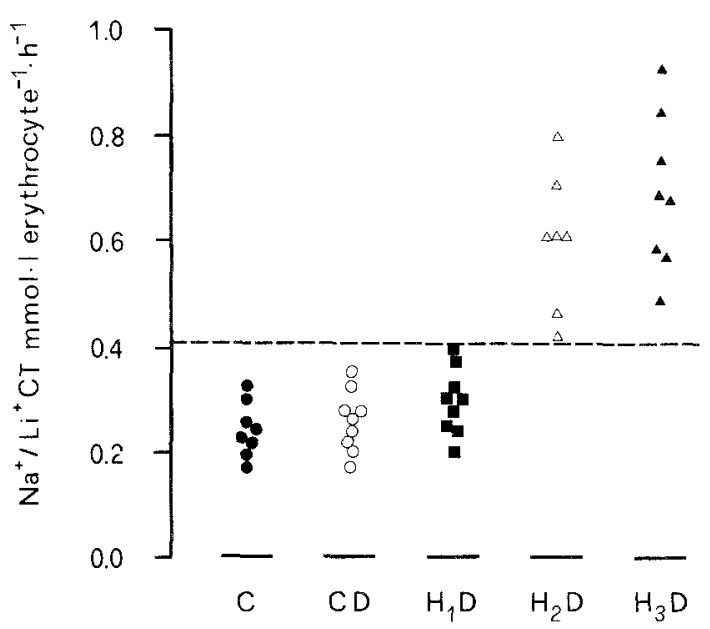

Fig. 2. Sodium-lithium countertransport $\left(\mathrm{Na}^{+} / \mathrm{Li}^{+} \mathrm{CT}\right)$ activity in erythrocytes in eight control subjects (C), in nine normotensive (CD) and seven hypertensive with high $\left(\mathrm{H}_{2} \mathrm{D}\right)$, nine hypertensive with normal $\left(\mathrm{H}_{1} \mathrm{D}\right)$ and eight hypertensive with high sodium-lithium countertransport activity and microalbuminuria $\left(\mathrm{H}_{3} \mathrm{D}\right)$ Type 1 (insulin-dependent) diabetic patients. The broken the line indicates the upper limit of normal population

albumin at an infusion rate of $50 \mathrm{ml}$ over $150 \mathrm{~min}$ (placebo). One week after Study 1, all subjects were given a second angiotensin II infusion with procedures identical to those of Study 1 except that indomethacin (Liometacen, Master, Pharma, Parma, Italy) was given orally to all subjects ( $50 \mathrm{mg}$ twice per day) for the preceding 7 days. On the day of the angiotensin II infusion indomethacin was administered intravenously throughout the experimental period $\left(15 \mu \mathrm{g} \cdot \mathrm{min}^{-1} \cdot \mathrm{kg}^{-1}\right)$ diluted in $154 \mathrm{mmol} / 1 \mathrm{NaCl}$ containing $0.5 \%$ human serum albumin at an infusion rate of $50 \mathrm{ml}$ per $150 \mathrm{~min}$ (Study 2).

Baseline overnight fasting glomerular filtration rate was measured in all diabetic and non-diabetic subjects after 30 days of indomethacin treatment ( $50 \mathrm{mg}$ twice daily) following the procedures described previously. 


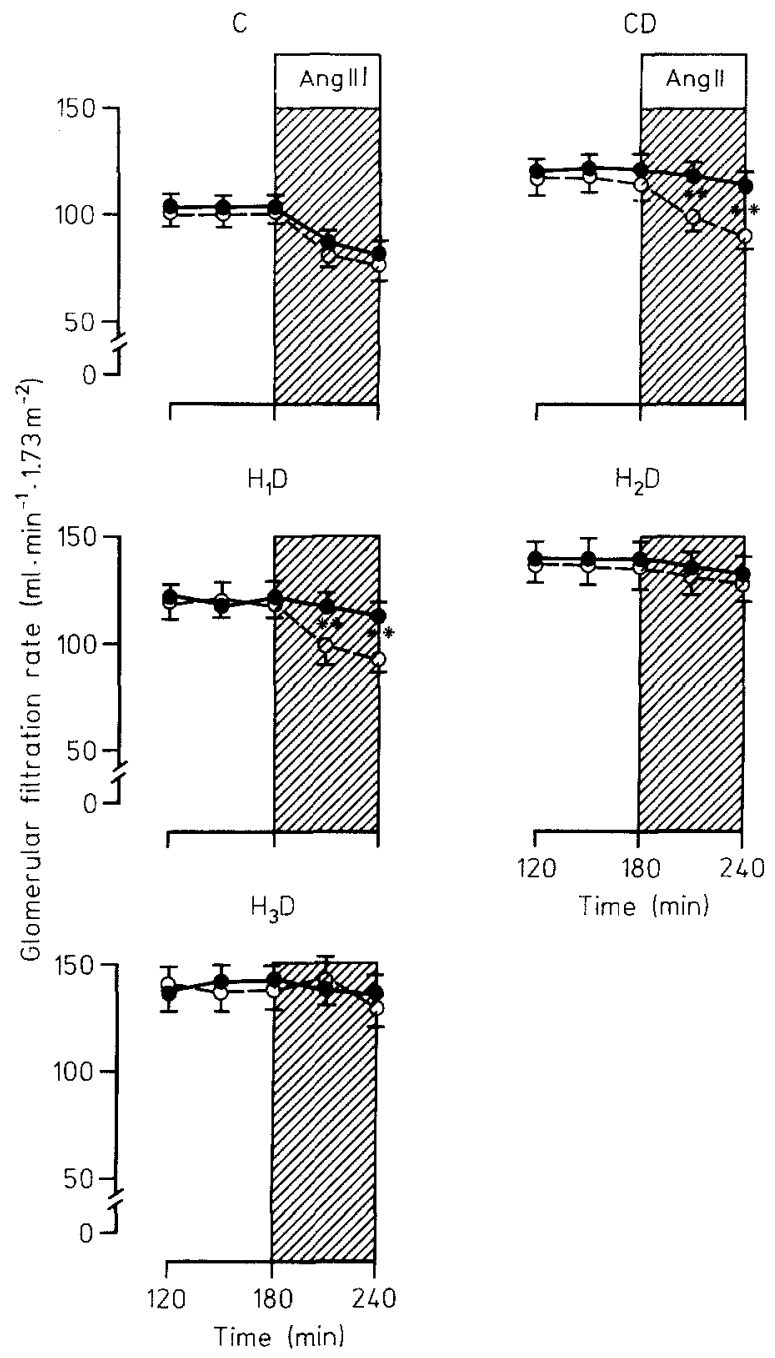

Fig. 3. Mean \pm SEM glomerular filtration rate at baseline and during angiotensin II infusion (Ang II) in eight control subjects (C), in nine normotensive $(C D)$, in nine hypertensive with normal $\left(\mathrm{H}_{1} \mathrm{D}\right)$, in seven hypertensive with high $\left(\mathrm{H}_{2} \mathrm{D}\right)$ and in eight hpyertensive with high sodium-lithium activity and microalbuminuria $\left(\mathrm{H}_{3} \mathrm{D}\right)$ Type 1 (insulin-dependent) diabetic patients. Continuous line indicates the placebo Study 1 and broken line the indomethacin Study 2. *** $p<0.01$ placebo vs indomethacin

\section{Measurements}

GFR and RPF were estimated by counting ${ }^{51} \mathrm{Cr}$ and ${ }^{125} \mathrm{I}$ in plasma and urine [19-22]. Albumin concentrations in urine [23] and free insulin [24] in plasma were measured by RIA technique. Blood glucose was measured by a glucose oxidase method (Beckman Instruments, Fullerton, Calif., USA) [25]. Plasma renin activity was measured by RIA technique [26]. Haemoglobin $\mathrm{A}_{1 \mathrm{c}}$ levels were determined using the BioRad (Richmond, Calif., USA) microcolumn chromatographic technique [27]. Plasma proteins and plasma albumin were measured using a Technicon RA-1000 multichannel autoanalyser. Haematocrit was determined by coulter counter. Sodium was measured in plasma and urine by flame photometry with lithium as an internal standard as indicated elsewhere $[19,22]$. Urinary $\mathrm{PGE}_{2}$, 6-ketoPGF $F_{1} \alpha$, and $\mathrm{T} \times \mathrm{B}_{2}$ were measured by RIA technique. $1000 \mathrm{cpm} 3 \mathrm{H}-\mathrm{PGE}_{2}(160 \mathrm{Ci} / \mathrm{mmol}$, Amersham) 3H-6-ketoPGF $\alpha$ (151 Ci/mmol, Amersham) $3 \mathrm{H}-\mathrm{T} \times \mathrm{B}_{2}(200 \mathrm{Ci} / \mathrm{mmol}$, Amersham $)$, were added to $5 \mathrm{ml}$ urine samples acidified to $\mathrm{pH} 4.0$ with hydrochloric acid, and extracted on an octadecyl silicic microcolumn (SepPak, Waters Milano, Italy ) following the method of Powell [28]. The extracts were re-suspended in methanol and eluted isocratically with acetonitrile: water:benzene: acetic acid 30: 69.7: 0.2: 01 on a C18 reverse phase micro-Bondpak column (Waters) at a flow rate of $2 \mathrm{ml} / \mathrm{min}$ [29-31]. This procedure is able to isolate urinary $\mathrm{T} \times \mathrm{B}_{2}$ from 2.3 dinor $\mathrm{T} \times \mathrm{B}_{2}$ [32]. The retention time of $\mathrm{PGE}_{2}$ was 660 , of 6 ketoPGF $\alpha, 300$, of $\mathrm{T} \times \mathrm{B}_{2}, 450$. Recovery was $55 \pm 19 \%$ for $\mathrm{PGE}_{2}$, $82 \pm 17 \%$ for 6 -ketoPGF $\alpha, 41 \pm 10 \%$ for $\mathrm{T} \times \mathrm{B}_{2}$. For RIA of $\mathrm{PGE}_{2}$, anti-PGE 2 serum was purchased from the Pasteur Institute, Paris, France; for RIA of 6-ketoPGF $\alpha$ and $\mathrm{T} \times \mathrm{B}_{2}$ a kit was purchased from Amersham. After overnight incubation, separation of antibody-bound and free fractions was obtained with charcoal-dextran. A fasting blood sample was taken in a $30 \mathrm{ml}$ heparin-treated syringe for measurements of $\mathrm{Na}^{+} / \mathrm{Li}^{+}$countertransport as described by Canessa et al. [6] and modified by Mangili et al. [8]. In order to have a reference value for $\mathrm{Na}^{+} / \mathrm{Li}^{+}$countertransport activity in erythrocytes in normal subjects, 35 normotensive normal subjects with no family history of hypertension were identified in the Internal Medicine Department, University of Padova and in the Metabolic Medicine Department of UMDS, Guy's Hospital, London. Mean plus $2 \mathrm{SD} \mathrm{Na}+/ \mathrm{Li}^{+}$countertransport activity in these subjects was $0.41 \mathrm{mmol} \cdot \mathrm{L}$ erythrocytes ${ }^{-1} \cdot \mathrm{h}$. B mode ultrasound imaging technique was used to determine the intimal plus medial thickness in both common carotid arteries. The average value of the two measurements was then used for statistical comparison. This echographic technique has been recently validated comparing ultrasound imaging and intimal plus medial thickness measurements on pathologic examination [33].

\section{Calculations and statistical analysis}

Clearances were calculated using the standard formula and protein excretion rate by multiplying concentrations by the urine flow rate. Renal vascular resistance (RVR) was calculated as $\left[\mathrm{MBP} \times\left(1-\mathrm{H}_{\mathrm{c}} \mathrm{T}\right) / \mathrm{RPF}\right] \times 100$, where MBP is mean blood pressure (calculated as diastolic blood pressure $+1 / 3$ pulse pressure), $\mathrm{H}_{\mathrm{c}} \mathrm{T}$ is haematocrit and RPF is renal plasma flow. Results at baseline and at each hour time-point represent the mean of the measurements made within each one-hour period. Data were analysed by two-way analysis of variance for repeated measurements. If two-factor analysis of variance revealed a significant difference between groups and between times, Newman-Keuls test was used to determine the specific levels between which the difference occurred. Spearman-analysis was used to assess the correlation coefficient between the decrease in GFR and $\mathrm{Na}^{*} / \mathrm{Li}^{+}$countertransport during indomethacin infusion along with angiotenin II administration. Chi-square statistical analysis was used when appropriate. Data are given as mean $\pm S E M$ unless otherwise stated.

\section{Results}

Both normotensive and hypertensive-microalbuminuric Type 1 diabetic patients had higher baseline GFR and RPF values (normotensive Type 1 diabetic patients: $122 \pm 7, \quad p<0.05$, and $545 \pm 49, \quad p<0.01, \mathrm{ml} \cdot \mathrm{min}$ $1.1 .73 \mathrm{~m}^{-2}$; hypertensive-microalbuminuric Type 1 diabetic patients: $131 \pm 8, p<0.05$, and $576 \pm 51, p<0.01$, $\left.\mathrm{ml} \cdot \mathrm{min}^{-1} \cdot 1.73 \mathrm{~m}^{-2}\right)$ than normal subjects $(106 \pm 6$ and $509 \pm 37 \mathrm{ml} \cdot \mathrm{min}^{-1} \cdot 1.73 \mathrm{~m}^{-2}$ ).

Ang II-induced decrease in GFR and RPF was lower in normotensive diabetic patients $(-6 \pm 2$ and $64 \pm 13 \mathrm{ml} \cdot \mathrm{min}^{-1} \cdot 1.73 \mathrm{~m}^{-2},-5 \%$ and $-12 \%, p<0.01$ and $p<0.01$, respectively) and in hypertensive-microalbuminuric diabetic patients $(-7 \pm 2$ and $-71 \pm 13$, $p<0.01 \mathrm{ml} \cdot \mathrm{min}^{-1} \cdot 1.73 \mathrm{~m}^{-2} ;-6 \%$ and $-13 \%, p<0.01$ and $p<0.01$ vs normal subjects, respectively) than in normal subjects $\left(-21 \pm 3\right.$ and $-174 \pm 26 \mathrm{ml} \cdot \mathrm{min}^{-1} \cdot 1.73 \mathrm{~m}^{-2}$; $-20 \%$ and $-34 \%$, respectively). The urinary excretion 


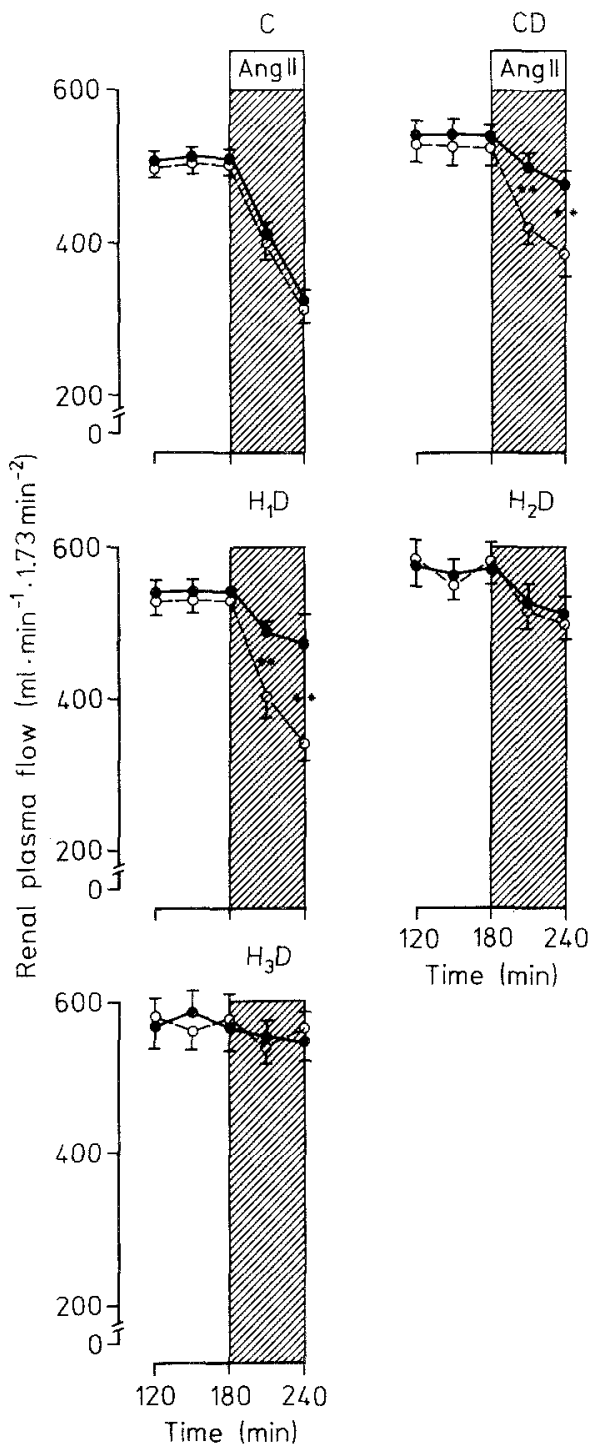

Fig.4. Mean \pm SEM renal plasma flow in eight control (C) subjects, in nine normotensive $(C D)$, in nine hypertensive with normal $\left(\mathrm{H}_{3} \mathrm{D}\right)$ in seven hypertensive with high $\left(\mathrm{H}_{2} \mathrm{D}\right)$ and in eight with high sodium-lithium countertransport activity and microalbuminuria $\left(\mathrm{H}_{3} \mathrm{D}\right)$ Type 1 diabetic patients. Continuous line indicates the placebo Study 1 and broken line indomethacin Study 2.** $p<0.01$ placebo vs indomethacin rate of $\mathrm{PGE}_{2}$ (normotensive diabetic patients: $1913 \pm 117 \mathrm{pg} / \mathrm{min}, \quad p<0.01$; hypertensive microalbuminuric diabetic patients: $1872 \pm 173 \mathrm{pg} / \mathrm{min}, p<0.01$ ) of 6-ketoPGF $\alpha$ (normotensive diabetic patients: $982 \pm 106 \mathrm{pg} / \mathrm{min}, \quad p<0.01$; hypertensive microalbuminuric diabetic patients: $934 \pm 103 \mathrm{pg} / \mathrm{min}$ ) but not of $\mathrm{T} \times \mathrm{B}_{2}$ (normotensive diabetic patients: $383 \pm 60, p<0.01$; hypertensive-microalbuminuric diabetic patients: $379 \pm 88 \mathrm{pg} / \mathrm{min}$ ) was significantly higher than in normal subjects ( $\mathrm{PGE}_{2}: 736 \pm 112 ; 6$ ketoPGF $\alpha: 413 \pm 72$; and $\mathrm{T} \times \mathrm{B}_{2}: 256 \pm 36$ ). Baseline values of GFR and RPF were not significantly influenced by indomethacin treatment in normal subjects or diabetic patients. On the contrary, indomethacin enhanced the Ang II-induced decrease in GFR in the normotensive, hypertensive and microalbuminuric Type 1 diabetic patients $\left(-18 \pm 3 \mathrm{ml} \cdot \mathrm{min}^{-1}\right.$. $1.73 \mathrm{~m}^{-2} ;-15 \% \quad p<0.01$ placebo vs indomethacin) but not in normal subjects. Similarly indomethacin enhanced the Ang II-induced decrease in RPF in the normotensive and the hypertensive and microalbuminuric Type 1 diabetic patients $\left(-135 \pm 29 \mathrm{ml} \cdot \mathrm{min}^{-1} \cdot 1.73 \mathrm{~m}^{-2} ;-25 \%\right.$ $p<0.01$ placebo vs indomethacin) but not in the normal subjects.

However, the action of Ang II on kidney haemodynamics was not similar in all Type 1 diabetic patients during cyclooxygenase inhibition. The administration of indomethacin was capable of restoring normal patterns of Ang II-induced changes in GFR and RPF in some, but not in all, patients with Type 1 diabetes.

In order to elucidate the reasons accounting for the differences in the renal haemodynamic response to Ang II infusion in Type 1 diabetic patients during indomethacin administration, we investigated the relationship between the absolute decrease in GFR following Ang II challenge and the activity of sodium lithium countertransport activity in erythrocytes. A highly significant inverse correlation was found between these two parameters (Fig. 1), suggesting that those patients with elevated sodium-lithium countertransport activity in erythrocytes were to some extent resistant to the action of Ang II, even during cyclooxygenase inhibition. To gain further insights in to the nature of such a relationship we divided the hypertensive

Table 2. Mean \pm SEM values of filtration fraction, renal vascular resistance and diastolic blood pressure during placebo and indomethacin treatment at baseline (Base) and during angiotensin II infusion (Ang II) in control subjects and in $\mathrm{CD}, \mathrm{H}_{1} \mathrm{D}, \mathrm{H}_{2} \mathrm{D}$ and $\mathrm{H}_{3} \mathrm{D}$ patients

\begin{tabular}{|c|c|c|c|c|c|c|c|c|c|c|c|}
\hline & & \multicolumn{2}{|c|}{$\begin{array}{l}\text { Normotensive } \\
\text { control subjects } \\
\text { (C) }\end{array}$} & \multicolumn{2}{|c|}{$\begin{array}{l}\text { Normotensive } \\
\text { diabetic patients } \\
\text { (CD) }\end{array}$} & \multicolumn{2}{|c|}{$\begin{array}{l}\text { Hypertensive diabetic } \\
\text { patients with normal } \\
\mathrm{Na}^{+} / \mathrm{Li}^{+} \mathrm{CT}\left(\mathrm{H}_{1} \mathrm{D}\right)\end{array}$} & \multicolumn{2}{|c|}{$\begin{array}{l}\text { Hypertensive diabetic } \\
\text { patients with high } \\
\mathrm{Na}^{+} / \mathrm{Li}^{-} \mathrm{CT}\left(\mathrm{H}_{2} \mathrm{D}\right)\end{array}$} & \multicolumn{2}{|c|}{$\begin{array}{l}\text { Hypertensive and mi- } \\
\text { croalbuminuric diabetic } \\
\text { patients with high } \\
\mathrm{Na}^{+} / \mathrm{Li}^{+} \mathrm{CT}\left(\mathrm{H}_{3} \mathrm{D}\right)\end{array}$} \\
\hline & & Base & Ang II & Base & Ang II & Base & Ang II & Base & Ang II & Base & Ang II \\
\hline \multirow[t]{2}{*}{$\begin{array}{l}\text { Filtration } \\
\text { fraction (\%) }\end{array}$} & \multirow{2}{*}{$\begin{array}{l}\text { Placebo } \\
\text { Indometh- } \\
\text { acin }\end{array}$} & $20.4 \pm 1.3$ & $24.6 \pm 1.4^{b}$ & $21.4 \pm 1.4$ & $23.9 \pm 1.5^{\mathrm{b}}$ & $21.5 \pm 1.8$ & $23.8 \pm 1.9^{b}$ & $24.1 \pm 1.8$ & $25.12 \pm 1.6^{\mathrm{b}}$ & $24.2 \pm 1.6$ & $25.1 \pm 1.4^{\mathrm{b}}$ \\
\hline & & $20.3 \pm 1.4$ & $24.0 \pm 1.6^{b}$ & $20.4 \pm 1.5$ & $23.7 \pm 1.4^{b}$ & $21.6 \pm 1.7$ & $26.9 \pm 1.7^{\mathrm{b}, \mathrm{d}}$ & $23.9 \pm 1.6$ & $26.2 \pm 1.4^{b}$ & $23.8 \pm 1.7$ & $26.5 \pm 1.4^{b}$ \\
\hline $\begin{array}{l}\text { Renal vascular } \\
\text { resistance }\end{array}$ & Placebo & $119 \pm 12$ & $206 \pm 14^{b}$ & $111 \pm 21$ & $135 \pm 19^{a}$ & $127 \pm 16$ & $135 \pm 20^{a}$ & $120 \pm 12$ & $131 \pm 15^{\mathrm{b}}$ & $121 \pm 10$ & $131 \pm 14^{\mathrm{b}}$ \\
\hline \multirow[t]{2}{*}{$\begin{array}{l}\text { Diastolic blood } \\
\text { pressure (mmHg) }\end{array}$} & \multirow{2}{*}{$\begin{array}{l}\text { Placebo } \\
\text { Indometh- } \\
\text { acin }\end{array}$} & $82 \pm 2$ & $93 \pm 1^{b}$ & $83 \pm 2$ & $90 \pm 1^{a}$ & $99 \pm 3$ & $106 \pm 3^{\mathrm{a}}$ & $100 \pm 2$ & $104 \pm 2^{\mathrm{b}}$ & $100 \pm 2$ & $106 \pm 3^{b}$ \\
\hline & & $81 \pm 1$ & $94 \pm 2^{b}$ & $84 \pm 2$ & $94 \pm 1^{\mathrm{a}}$ & $98 \pm 2$ & $109 \pm 2^{\mathrm{a}}$ & $100 \pm 2$ & $107 \pm 2^{b}$ & $100 \pm 2$ & $106 \pm 3^{\mathrm{b}}$ \\
\hline
\end{tabular}

${ }^{\mathrm{a}} p<0.05,{ }^{\mathrm{b}} p<0.01$ Ang II vs Base; ${ }^{\mathrm{c}} p<0.05,{ }^{\mathrm{d}} p<0.01$ indomethacin vs placebo

$\mathrm{Na}^{+} / \mathrm{Li}^{+} \mathrm{CT}=$ sodium-lithium countertransport 


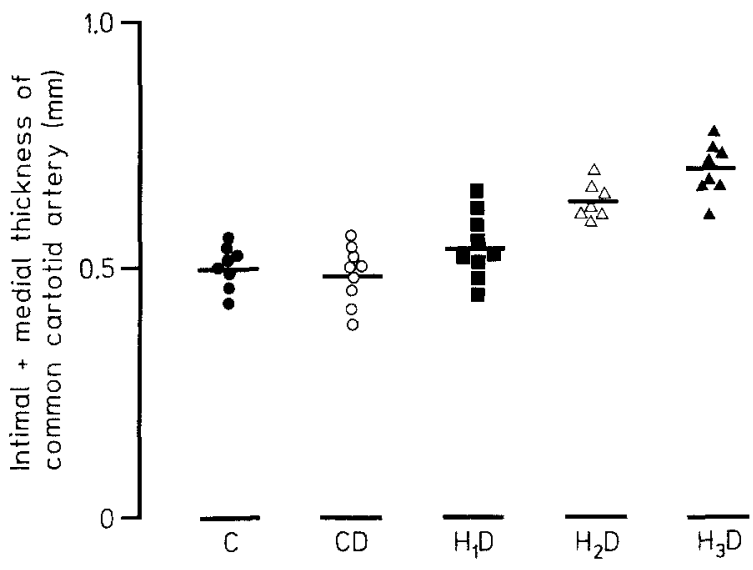

Fig.5. B mode ultrasound imaging of intimal plus medial thickness of common carotid arteries in the five groups of control subjects (C) and in normotensive $(\mathrm{CD})$ and hypertensive with normal $\left(\mathrm{H}_{1} \mathrm{D}\right)$ with high sodium-lithium countertransport activity $\left(\mathrm{H}_{2} \mathrm{D}\right)$ with high sodium-lithium countertransport activity and microalbuminura $\left(\mathrm{H}_{3} \mathrm{D}\right)$ Type 1 diabetic patients

patients with Type 1 diabetes in two subgroups: i.e. with an activity of sodium-lithium countertransport in erythrocytes lower $\left(\mathrm{H}_{1} \mathrm{D}\right)$ and higher $\left(\mathrm{H}_{2} \mathrm{D}\right)$ than $0.41 \cdot \mathrm{L}$ erythrocytes $^{-1} \cdot \mathrm{h}^{-1}$; that is the mean value plus 2 SD of the sodiumlithium countertransport in normotensive normal subjects.

Figure 2 shows the sodium-lithium countertransport activity in the erythrocytes of the normotensive control subjects (C), of normotensive (CD) and hypertensive Type 1 diabetic patients with normal $\left(\mathrm{H}_{1} \mathrm{D}\right)$ and high $\left(\mathrm{H}_{2} \mathrm{D}\right)$ sodium-lithium countertransport activity and hypertensive diabetic patients with microalbuminuria and high sodium-lithium countertransport activity $\left(\mathrm{H}_{3} \mathrm{D}\right)$. The five groups of normal and diabetic subjects were comparable for gender, smoking habits, and body mass index (Table 1). Age and diabetes duration were similar in the $\mathrm{CD}, \mathrm{H}_{1} \mathrm{D}$ and $\mathrm{H}_{2} \mathrm{D}$ patients. $\mathrm{H}_{3} \mathrm{D}$ were older and had a significantly longer duration of diabetes. The three groups of hypertensive patients $\left(\mathrm{H}_{1} \mathrm{D}\right.$ and $\mathrm{H}_{2} \mathrm{D}$ and $\left.\mathrm{H}_{3} \mathrm{D}\right)$ had similar blood pressure levels, but duration of antihypertensive treatment was longer in $\mathrm{H}_{3} \mathrm{D}$. Plasma sodium and potassium concentrations were similar in normal control subjects $(\mathrm{C})$ and $\mathrm{CD}, \mathrm{H}_{1} \mathrm{D}, \mathrm{H}_{2} \mathrm{D}$ and $\mathrm{H}_{3} \mathrm{D}$ diabetic patients, as was sodium and potassium excretion rate (Table 1). Plasma renin activity was significantly lower only in CD on ad- mission to the hospital ward (Table 1). Serum creatinine was similar in all four groups of subjects and patients (Table 1). Albumin excretion rate was similar in $\mathrm{C}$ subjects $(6 \pm 2 \mu \mathrm{g} / \mathrm{min})$ and $\mathrm{CD}(8 \pm 3)$, in $\mathrm{H}_{1} \mathrm{D}(7 \pm 3)$ and $\mathrm{H}_{2} \mathrm{D}(10 \pm 3)$ patients, whereas significantly higher values were found in $\mathrm{H}_{3} \mathrm{D}$ patients $\left(46 \pm 6 p<0.05 \mathrm{vs} \mathrm{C}, \mathrm{CD}, \mathrm{H}_{1} \mathrm{D}\right.$, $\mathrm{H}_{2} \mathrm{D}$ ) (Table 1).

The response to Ang II infusion during placebo and indomethacin treatment was then evaluated separately in these five groups of normal subjects and patients with Type 1 diabetes identified by different activities of sodium-lithium countertransport. This different approach in the analysis of the results of the present study revealed that baseline GFR were more elevated in $\mathrm{H}_{2} \mathrm{D}$ and $\mathrm{H}_{3} \mathrm{D}$ than in $\mathrm{H}_{1} \mathrm{D}$ hypertensive patients $(136 \pm 7$ and $138 \pm 6 \mathrm{ml} \cdot \mathrm{min}^{-1} \cdot 1.73 \mathrm{~m}^{-2}$ vs $117 \pm 5, \quad p<0.01$ and $p<0.01$, respectively) (Fig.3). Similar differences were found with regard to RPF.

Furthermore, indomethacin treatment restored a normal response to Ang II in CD and $\mathrm{H}_{1} \mathrm{D}$ but not in $\mathrm{H}_{2} \mathrm{D}$ and $\mathrm{H}_{3} \mathrm{D}$ diabetic patients with Type 1 diabetes (Figs. 3 and 4). Diabetic patients also had an impaired blood pressure and renal vascular resistance response to Ang II (Table 2). The inibition of cyclooxygenase by indomethacin ameliorated the response in filtration fraction and in renal vascular resistance to Ang II challenge in the $\mathrm{CD}$ and $\mathrm{H}_{1} \mathrm{D}$ but not in the $\mathrm{H}_{2} \mathrm{D}$ and $\mathrm{H}_{3} \mathrm{D}$ patients (Table 2). Interestingly, no significant differences in the renal and systemic haemodynamic response to Ang II were shown by normal subjects between the two studies with placebo and indomethacin treatments. The urinary excretion rate of $\mathrm{PGE}_{2}$, $6 \mathrm{ketoPGF}_{1} \alpha$ and $\mathrm{T} \times \mathrm{B}_{2}$ were markedly and similarly inhibited both in normal subjects and $\mathrm{CD}, \mathrm{H}_{1} \mathrm{D}, \mathrm{H}_{2} \mathrm{D}$ and $\mathrm{H}_{3} \mathrm{D}$ patients with Type 1 diabetes by indomethacin treatment (Table 3).

Baseline overnight fasting GFR after 30 days of indomethacin treatment was $104 \pm 4 \mathrm{ml} \cdot \mathrm{min}^{-1} \cdot 1.73 \mathrm{~m}^{-2}$ in $\mathrm{C}$ subjects (NS vs placebo); $111 \pm 5(p<0.05)$ in CD patients; $113 \pm 6(p<0.01)$ in $\mathrm{H}_{1} \mathrm{D}$ patients and $120 \pm 7$ (NS vs placebo) in $\mathrm{H}_{2} \mathrm{D}$ patients and $128 \pm 6$ (NS vs placebo) in $\mathrm{H}_{3} \mathrm{D}$ patients. Thus, chronic indomethacin treatment resulted in a significant decrease in GFR only in CD and $\mathrm{H}_{1} \mathrm{D}$ patients but not in normal subjects $(\mathrm{C})$ or hypertensive and microalbuminuric diabetic patients with high sodium-lithium countertransport activity $\left(\mathrm{H}_{2} \mathrm{D}\right.$ and $\left.\mathrm{H}_{3} \mathrm{D}\right)$.

Table 3. Mean \pm SEM prostaglandinin urinary excretion rate during placebo and indomethacin (baseline plus angiotensin II infusion periods) in control subjects and in $\mathrm{CD}, \mathrm{H}_{1} \mathrm{D}, \mathrm{H}_{2} \mathrm{D}$ and $\mathrm{H}_{3} \mathrm{D}$ patients

\begin{tabular}{|c|c|c|c|c|c|c|}
\hline & & $\begin{array}{l}\text { Normotensive } \\
\text { control subjects } \\
\text { (C) }\end{array}$ & $\begin{array}{l}\text { Normotensive dia- } \\
\text { betic patients } \\
\text { (CD) }\end{array}$ & $\begin{array}{l}\text { Hypertensive diabe- } \\
\text { tic patients with nor- } \\
\text { mal Na }{ }^{+} / \mathrm{Li}^{+} \mathrm{CT} \\
\left(\mathrm{H}_{1} \mathrm{D}\right)\end{array}$ & $\begin{array}{l}\text { Hypertensive dia- } \\
\text { betic patients with } \\
\text { high } \mathrm{Na}^{+} / \mathrm{Li}^{+} \mathrm{CT} \\
\left(\mathrm{H}_{2} \mathrm{D}\right)\end{array}$ & $\begin{array}{l}\text { Hypertensive and microal- } \\
\text { buminuric diabetic patients } \\
\text { with high } \mathrm{Na}^{+} / \mathrm{Li}^{+} \mathrm{CT} \\
\left(\mathrm{H}_{3} \mathrm{D}\right)\end{array}$ \\
\hline $\begin{array}{l}\text { 6-keto } \text { PGF }_{1} \alpha \\
\text { (pg/min) }\end{array}$ & $\begin{array}{l}\text { Placebo } \\
\text { Indomethacin }\end{array}$ & $\begin{array}{l}413 \pm 72 \\
106 \pm 22^{b}\end{array}$ & $\begin{array}{l}982 \pm 106^{c} \\
318 \pm 104^{a}\end{array}$ & $\begin{array}{r}1221 \pm 144^{\mathrm{c}} \\
294 \pm 98^{\mathrm{b}}\end{array}$ & $\begin{array}{c}914 \pm 229 \\
2741 \pm 41^{b}\end{array}$ & $\begin{array}{l}821 \pm 184^{c} \\
261 \pm 69^{b}\end{array}$ \\
\hline
\end{tabular}

${ }^{a} p<0.05,{ }^{b} p<0.01$ Indomethacin vs Placebo; ${ }^{c} p<0.05$, ${ }^{\mathrm{d}} p<0.01 \mathrm{CD}, \mathrm{H}_{1} \mathrm{D}, \mathrm{H}_{2} \mathrm{D}$ and $\mathrm{H}_{3} \mathrm{D}$ patients vs $\mathrm{C}$ subjects. PGE $\mathrm{E}_{2}=$ prostaglandin $\mathrm{E}_{2} . \mathrm{Na}^{+} / \mathrm{Li}^{+} \mathrm{CT}=$ sodium-lithium countertransport, 6 -keto $\mathrm{PGF}_{1} \alpha=$ prostaglandin 6 -ketoPGF $\alpha$ and $\mathrm{T} \times \mathrm{B}_{2}=$ tromboxane $\mathrm{B}_{2}$ 
Ultrasound B mode imaging of common carotid arteries showed that the intimal plus medial thickness of the arteries was significantly lower $(0.50 \pm 0.01 \mathrm{~mm})$ in $C$ subjects, $(0.49 \pm 0.01 \mathrm{~mm})$ in $C D$ patients, and $(0.53 \pm 0.01 \mathrm{~mm})$ in $\mathrm{H}_{1} \mathrm{D}$ patients than $(0.64 \pm 0.03 \mathrm{~mm}$ $p<0.01)$ in $\mathrm{H}_{2} \mathrm{D}$ patients and $(0.69 \pm 0.04 \mathrm{~mm} p<0.01)$ in $\mathrm{H}_{3} \mathrm{D}$ patients (Fig. 5).

\section{Discussion}

The findings of the present study demonstrate that in patients with Type 1 diabetes: (1) the renal and systemic responsiveness to Ang II is impaired, (2) the urinary excretion rate of vasodilatory PGs is high, (3) the administration of the cyclooxygenase inhibitor, indomethacin, restores a normal renal and systemic response to Ang II and overnight fasting baseline glomerular filtration rate in diabetic patients with normal sodium-lithium countertransport activity in erythrocytes and (4) an elevated sodium-lithium countertransport activity identifies a subset of diabetic patients, with hypertension and microalbuminuria and with carotid artery hypertrophy, in whom renal haemodynamics remain abnormal despite the inhibiton of excessive prostaglandin synthesis.

In accordance with previous reports, Type 1 diabetic patients show a higher renal excretion rate of PGs [15-17]. Patients with Type 1 diabetes have increased urinary excretion rates mainly of vasodilatory $\mathrm{PGs}$, independent of the degree of metabolic control $[15,16]$ and, as suggested by the present study, also of the levels of blood pressure. It is not clear whether such abnormalities in PGs metabolism play a role in the pathogenesis of glomerular haemodynamic disturbances in Type 1 diabetes. In both human and animal diabetes a role for renal PGs in the hyperfiltration phenomenon has been advocated by some workers but denied by others [34-37].

The current finding that indomethacin administration restored a normal renal and systemic response to Ang II in diabetic patients who had elevated urinary excretion rate of PGs but not in normal subjects in whom the renal synthesis of eicosanoids was low, supports the view that a resistance to Ang II in Type 1 diabetes is secondary to an excessive renal synthesis of PGs, which antagonizes the modulation of renal haemodynamics by the renin-Ang II system.

These results in human subjects confirm a preliminary report of Inman et al. [38] and Sarubbi et al. [39] in diabetic rats, showing that the vascular bed in Type 1 diabetes does not properly respond to Ang II action. Furthermore, it has also been reported that the administration of prostacyclin $\left(\mathrm{PGI}_{2}\right)$ in human pregnancy attenuates both pressor and adrenocortical changes following Ang II challenge [40]. Indomethacin has been shown to eventually restore a normal responsiveness to Ang II in diabetic rats [38].

From a general point of view these findings lend support to the belief that vasodilatory PGs play an important intrarenal role in modulating the contractile effects of Ang II in humans [13]. With regard to the patients with Type 1 diabetes an attenuated hormonal action of Ang II, secondary to an excessive intrarenal synthesis of vasodilatory PGs, could help to determine a chronic arteriolar vasodilation leading to glomerular hyperfiltration.

On the other hand the present study shows that a subset of diabetic patients with hypertension and microalbuminuria without clinical nephropathy, had an impaired response to Ang II, even when the excessive synthesis of PGs had been significantly reduced by cyclooxygenase inhibitors.

In order to elucidate the mechanisms accounting for the different haemodynamic behaviour of this latter group of patients with Type 1 diabetes, we investigated the relationship between the renal response to Ang II and the activity of sodium-lithium countertransport in erythrocytes during indomethacin infusion. The rationale for such a study was suggested by previous reports that hyperfiltration is particularly evident only in a subset of patients with Type 1 diabetes [41] and is associated with elevated exchange in sodium-lithium countertransport erythrocytes [10]. A highly significant inverse correlation was found between the decrease in GFR and RPF and the rate of activity of sodium-lithium countertransport in the erythrocytes, even if the urinary excretion rate of PGs had been markedly inhibited by indomethacin in all diabetic patients.

Interestingly, the clinical features of these diabetic patients are quite similar to those shown by non-diabetic patients with "non-modulating" essential hypertension, who also have high average values of sodium-lithium countertransport activity in the erythrocytes and high frequency of positive family history of hypertension $[42,43]$.

More recently the clinical characteristics of "nonmodulating" hypertension, that is the abnormal response to Ang II and the capacity to handle oral sodium intake, have been found to be genetically inherited in subjects with essential hypertension [43].

However, the finding of an association between elevated sodium-lithium countertransport activity in erythrocytes and the impaired response to Ang II raises the question of whether these two phenomena are simply associated or whether such abnormalities in all membrane cation transport systems play a mechanistic role in determining altered haemodynamics at kidney level in a subset of diabetic patients. With regard to this latter hypothesis it has been shown that sodium-lithium countertransport activity is a mode of operation of sodium-hydrogen antiport $[44,45]$ and a good agreement has been found between the exchange rates of sodium-lithium and sodium-hydrogen in the erythrocytes of human subjects [46]. Theoretically, altered function of the sodium-hydrogen exchanger might explain several abnormalities at vascular and tissue level in the subset of diabetic patients characterized by elevated sodium-lithium countertransport activity. Changes in activity of the sodium-hydrogen exchanger would link abnormalities in cell growth with abnormalities in sodium homeostasis because the exchanger has been shown to be critically involved in both growth factor-stimulated cell division [7, 47] and agonist-stimulated sodium influx [48, 49]. Increased sodium- hydrogen exchange might result in a more sustained or more rapid mitogenetic response to growth factors [50]. Conversely, the binding of vasocon- 
strictor agents could enhance sodium-hydrogen antiport activity contributing to the abnormal vasoreactivity demonstrated by the diabetic patients with elevated sodium-lithium countertransport activity in the present study [7].

The results of the present study demonstrate that diabetic patients with elevated sodium-lithium countertransport in erythrocytes had an intimal plus medial thickness of the common carotid artery greater than that of normal subjects and of diabetic patients with normal sodium-lithium countertransport activity. Yap et al. [51] recently showed that amongst patients with essential hypertension, the subjects with an elevated sodium-lithium countertransport, despite levels of blood pressure similar to those with normal sodium-lithium countertransport, had electrocardiographic left ventricular hypertrophy. We have recently reported similar findings in Type 1 diabetic patients using ultrasound techniques [52].

It can be suggested that high sodium-lithium countertransport activity in erythrocytes is associated with cardiac and vascular abnormalities which can precede the increase in blood pressure and further deteriorate the deleterious effects of hypertension on cardiac function in a cohort of subjects characterized by genetic factors predisposing to cardiovascular cell replication and hyperplasia. With regard to this view it has been reported that cardiac hypertrophy does occur in spontaneously hypertensive rats, who are genetically characterized by high sodium-hydrogen antiport activity, before the appearance of increased blood pressure $[53,54]$. Also in humans, left ventricular muscle mass has been shown to be higher in the normotensive offspring of hypertensive parents than in control subjects with similar blood pressure, suggesting that factors other than a simple increase in blood pressure could contribute to determine cell growth and replication in these subjects [55].

In summary, the results of this study demonstrate that an excessive synthesis of vasodilatory PGs antagonizes the regulation by the renin-Ang II hormonal system of the systemic and renal haemodynamics in patients with Type 1 diabetes.

On the other hand a subgroup of hypertensive patients with Type 1 diabetes before the development of overt clinical nephropathy, who are identified by elevated sodium-lithium countertransport in erythrocytes, is characterized by abnormalities at functional, renal and morphological vascular level. It is interesting to point out that a similar behaviour with regard to the response to Ang II and to the other clinical parameters was also shown by the hypertensive subjects with high sodium-lithium countertransport and microalbuminuria. Since microalbuminuria has been shown to predict the development of overt nephropathy in Type 1 diabetes [4-5] it can be postulated that the clinical and physiological features described by the present study in Type 1 diabetic patients are to some extent associated with those diabetic patients who have a susceptibility to diabetic nephropathy. In these subjects the normalization of the urinary excretion rate of PGs does not restore a normal response to Ang II infusion and baseline glomerular filtration rate. It is suggested that abnormalities in cell growth and function at arteriolar level, cause a lower compliance to vascoconstrictor stimuli in a subset of patients with Type 1 diabetes, i. e. a vascular stiffness, which may determine tissue and particularly glomerular hyperfiltration and possibly a susceptibility to diabetic complications.

Acknowledgements. This work was supported by the Italian Centro Nazionale delle Ricerche (CNR Grant N.8879865 and 88715213)

\section{References}

1. Andersen AR, Christiansen JS, Andersen JK, Kreiner S, Deckert T (1983) Diabetic nephropathy in Type 1 (insulin-dependent) diabetes: an epidemiological study. Diabetologia 25 : 496-501

2. Krolewski AS, Warram JH, Christlieb AR, Bunsick ET, Kahn CR (1985) The changing natural history of nephropathy in type I diabetes. Am J Med 78: 785-794

3. Parving H-H, Smidt UM, Friisberg B, Bonnevie Nielsen V, Andersen AR (1981) A prospective study of glomerular filtratin rate and arterial blood pressure in insulin dependent diabetes with diabetic nephropathy. Diabetologia 20: 457-461

4. Viberti GC, Hill RD, Jarrett RJ, Argyroupoulos A, Mahmud U, Keen H (1982) Microalbuminuria as a predictor of clinical nephropathy in insulin-dependent diabetes mellitus. Lancet I: $1430-1432$

5. Mogensen CE, Christensen CK (1986) Predicting diabetic nephropathy in insulin-dependent patients. N Engl J Med 311: $89-93$

6. Canessa M, Adragna M, Solomon HS, Connolly TM, Tosteson DC (1980) Increased sodium-lithium countertransport in red cells of patients with essential hypertension. $\mathrm{N}$ Engl J Med 302: $772-776$

7. Mahmensmith RL, Aronson P (1985) The plasma membrane sodium hydrogen exchanger and its role in physiological and pathophysiological processes. Circ Res 56: 773-778

8. Mangili R, Bending JJ, Scott G, Li LK, Gupta A, Viberti GC (1988) Increased sodium lithium countertransport activity in red cells of patients with insulin dependent diabetes and nephropathy. N Engl J Med 318: 146-150

9. Krolewski AS, Canessa M, Warram JH et al. (1988) Predisposition to hypertension and susceptibility to renal disease in insulin dependent diabetes mellitus. N Engl J Med 318: 140-145

10. Carr S, Mbanya JC, Thomas T et al. (1990) Increase in glomerular filtration rate in patients with insulin-dependent diabetes and elevated erythrocytes sodium-lithium countertransport. $\mathrm{N}$ Engl J Med 322: 500-505

11. Jensen JS, Mathiesen ER, Norgaard K et al. (1990) Increased blood pressure and erythrocyte sodium-lithium countertransport activity are not inherited in diabetic nephropathy. Diabetologia 33: 619-624

12. Dunn MJ, Scharschmidt LA (1987) Prostaglandins modulate the glomerular actions of angiotensin II. Kidney Intern 31: S95-S101

13. Romero JC, Knox FG (1988) Mechanisms underlying pressurerelated natriuresis: the role of the renin-angiotensin and prostaglandin system. State of the art lecture. Hypertension 11: 724 728

14. Viberti GC, Wiseman MJ (1986) The kidney in diabetes: significance of early abnormalities. Clin Endocrinol Metab 15: 753-782

15. Viberti GC, Benigni A, Bognetti E, Remuzzi G, Wiseman MJ (1989) Glomerular hyperfiltration and urinary prostaglandins in type I diabetes mellitus. Diab Med 6: 219-223

16. Fioretto P, Trevisan R, Valerio et al. (1990) Impaired renal response to a meat meal in insulin-dependent diabetes: role of glucagon and prostaglandins. Am J Physiol 258: F675-F683

17. Gambardella S, Andreani D, Cancelli et al. (1988) Renal hemodynamics and urinary excretion rate of 6-keto-prostaglandin $F_{1} \alpha$ and thromboxane $B_{2}$ in newly diagnosed type I diabetic patients. Diabetes 37: 1044-1048 
18. National Diabetes Data Group (1979) Classification and diagnosis of diabetes mellitus and other categories of glucose intolerance. Diabetes 28: 1039-1053

19. Nosadini R, Trevisan R, Fioretto P et al. (1989) Kidney hemodynamics following ketone body and amino acid infusion in normal and IDDM patients. Diabetes 38: 75-83

20. Trevisan R, Nosadini R, Fioretto P et al. (1987) Ketone bodies increase glomerular filtration rate in normal man and in patients with Type 1 (insulin-dependent) diabetes mellitus. Diabetologia 30: 214-221

21. Fioretto P, Trevisan R, Velussi M et al. (1987) Glomerular filtration rate is increased in man by the infusion of both D, L-3-hydroxybutyrate acid and sodium D, L 3-hydroxybutyrate. J Clin Endocrinol Metab 65: 331-338

22. Trevisan R, Fioretto P, Semplicini A et al. (1990) Role of insulin and atrial natriuretic peptide in Na retention in insulin treated IDDM patients during isotonic volume expansion. Diabetes 39: 289-298

23. Keen H, Chlouverakis G (1963) An immunoassay method for urinary albumin at low concentrations. Lancet II: 913-914

24. Nagakawa S, Nakayama H, Sasaki et al. (1973) A simple method for the determination of serum free insulin levels in insulintreated patients. Diabetes 22:590-600

25. Huggett A, Nixon D (1957) Use of glucose oxidation peroxidase and odianisidine in determination of blood and urinary glucose. Lancet II: $368-370$

26. Sealey JF, Gerten-Baues J, Laragh JH (1972) The renin system variations in man measured by radioimmunoassay or bioassay. Kidney Int 1:240-249

27. Bio-Rad Laboratories (1938) Microcolumn chromatographic $\mathrm{HbA}_{\mathrm{c}}$ determination, Richmond, C. A., USA

28. Powell WS (1980) Rapid excretion of oxygenated metabolites of arachidonic acid from biological samples using octadecylsilyl silica. Prostaglandins 20:947-957

29. Whorton AR, Carr K, Smigel M, Walker L, Ellis K, Oates JA (1979) Reversed phase high performance liquid chromatography of prostaglandius for biological applications. J Chromatogr 163: 64-71

30. Zipser RD, Morrison A, Laffi G, Duke R (1985) Assay methods for 6-keto-prostaglandin $F_{1} \alpha$ in human urine. Comparison of chromatographic techniques with radioimmunoassay and gas chromatography-negative-ion chemical-ionization mass spectrometry. J Chromatogr 339: 1-9

31. Pinzani M, Laffi G, Meacci E, La Villa G, Cominelli F, Gentilini $P$ (1988) Intrarenal thromboxane $A_{2}$ generation reduces the furosemide-induced sodium and water diuresis in cirrhosis with ascites. Gastroenterology 95: 1081-1087

32. Gentilini P, Laffi G, Maecci E (1988) Effect of OKY 046, a thromboxane synthase inhibitor, on renal function in nonazotemic cirrhotic patients with ascites. Gastroenterology 94 : 1470-1477

33. Pignoli P, Tremoli E, Poli A, Oreste P, Paoletti R (1986) Intimal plus medial thickness of the arterial wall: a direct measurement with ultrasound imaging. Circulation 74: 1399-1406

34. Wilson TW, Tan LK (1985) Low plasma renin activity in diabetes: relation to urine prostaglandin excretion. Diabetes 34: 145-150

35. Esmatjes E, Fernandez MR, Haliperin I et al. (1985) Renal hemodynamic abnormalities in patients with short-term insulindependent diabetes mellitus: role of prostaglandins. J Clin Endocrinol Metab 60: 1231-1236

36. Bank N, Lahorra MAG, Aynedjian HS, Scholondorff D (1988) Vasoregulatory hormones and the hyperfiltration of diabetes. Am J Physiol 23: F202-209

37. Christiansen JS, Rasmussen FB, Parving HH (1985) Short-term inhibition of prostaglandin synthesis has no effect on the elevated glomerular filtration rate of early insulin-dependent diabetes. Diab Med 2: 17-20

38. Inman SR, Fleming JT (1989) Reduced renal microvascular reactivity to angiotensin II in early diabetes: role of prostaglandins. Diabetes 38: 120A (Abstract)
39. Sarubbi D, Mc Giff J, Quituy J (1989) Renal vascular respones and eicosanoids release in diabetic rats. Am $J$ Physiol 257 : F762-F768

40. Broughton Pipkin F, Morrison R, O'Brien PMS (1989) Prostacyclin attenuates both the pressor and adrenocortical response to angiotensin II in human pregnancy. Clin Science 76: 529-534

41. Mogensen CE, Andersen MJ (1975) Increased kidney size and glomerular filtration rate in untreated juvenile diabetes. Normalization by insulin-treatment. Diabetologia 11:221-224

42. Redgrave J, Canessa M, Gleason R, Hollenberg NK, Williams GH (1989) Red blood cell lithium sodium countertransport in non-modulating essential hypertension. Hypertension 13: $721-726$

43. Hollenberg NK, Williams GH, Dluby RG (1989) Evidence for heritability of non-modulating essential hypertension. Hypertension 13: 884-889

44. Aronson PS (1982) Red cell sodium-lithium countertransport and essential hypertension. N Engl J Med 307: 317

45. Canessa M, Morgan K, Semplicini A (1988) Genetic differences in lithium-sodium exchange and regulation of the sodium-hydrogen exchanger in essential hypertension. J Cardiovasc Pharmacol 32: 1621-1627

46. Semplicini A, Mozzato MG, Samà B et al. (1989) Na/H and Li/Na exchange in red blood cells of normotensive and hypertensive patients, with insulin dependent diabetes mellitus. Am J Hypertens 2: 174-177

47. Pouyssegur J, Sadet C, Frandri A, L'Allemain G, Paris S (1984) A specific mutation abolishing $\mathrm{Na}^{+} / \mathrm{H}^{+}$antiport activity in hamster fibroblasts precludes growth at neutral and acidic $\mathrm{pH}$. Proc Natl Acad Sci USA 81:4833-4837

48. Smith JB, Brock TA (1983) Analysis of angiotensin stimulated $\mathrm{Na}^{-}$transport in cultured smooth muscle cell from rat aorta. $J$ Cell Physiol 114: 284-290

49. Owen N (1984) Platelet-derived growth factor stimulates $\mathrm{Na}^{+}$influx in vascular smooth muscle cells. Am J Physiol 247: C501-505

50. Moolenar W, Tsien R, Van der Saag P, De Laat S (1983) $\mathrm{Na}^{+} / \mathrm{H}^{+}$ exchange and cytoplasmatic $\mathrm{pH}$ in the action of growth factors in human fibroblasts. Nature 304: 645-648

51. Yap L, Arrazzola A, Soria F, Diez J (1989) Is there increased cardiovascular risk in essential hypertensive patients with abnormal kinetics of red blood cell sodium-lithium countertransport? Hypertension 7: 667-673

52. Fioretto P, Trevisan R, Doria A et al. (1990) High sodium-lithium countertransport activity in red blood cells is associated with insulin resistance and cardiac and renal hypertrophy in insulin-dependent diabetes before the onset of nephropathy. Diabetologia: 33: 6A (Abstract)

53. Clubb FJ, Bell D, Krisman JD, Bíshop SP (1987) Myocardial cell growth and blood pressure development in neonatal spontaneous hypertensive rats. Labor Invest 56: 189-197

54. Berk BC, Vallega G, Muslin AJ, Gordon HM, Canessa M, Alexander RW (1988) Spontaneously hypertensive rat vascular smooth muscle cells in culture exhibit increased growth and $\mathrm{Na}^{+} / \mathrm{H}^{+}$exchange. J Clin Invest 83: 822-829

55. Devereux RB (1990) Does increased blood pressure cause left ventricular hypertrophy or vice versa? Am Inter Med 112: $157-158$

Received: 26 September 1990

and in revised form: 19 April 1991

Dr. R. Nosadini

Istituto di Medicina Interna

Patologia Medica I ${ }^{a}$

Policlinico Universitario

Via Giustiniani, 2

I-35128 Padova

Italy 